\title{
Informational provision of the assessment of the potential of the innovative development of a territory*
}

\section{Belyaev Mikhail Konstantinovich Doctor of Economic Sciences Professor}

Head of the Chair of the Economics and Management of Projects in the Construction Industry

Volgograd State University of Architecture and Civil Engineering Volgograd, Russia belyaevmk@yandex.ru

\author{
Sokolova Svetlana Aleksandrovna \\ Candidate of Economic Sciences \\ Associate Professor \\ Chair of the Economics and \\ Management of Projects in the \\ Construction Industry \\ Volgograd State University of \\ Architecture and Civil Engineering \\ Volgograd, Russia \\ svetalekssok@yandex.ru
}

\author{
Batmanova Victoria Victorovna \\ Candidate of Economic Sciences \\ Associate Professor \\ Chair of International and Regional \\ Economics \\ Volgograd State University \\ Volgograd, Russia \\ vbatmanova@mail.ru
}

Abstract-The assessment of the potential of the innovative development of a territory is seen as an important and crucial problem exciting all the international community. In different time periods the potential of the innovative development was studied by L.S. Blyakhman, V.P. Efimov, K.M. Misko and others. However for the present moment there is no universal approach to the determination of the level of the potential of the innovative development of a territory.

The basic goal of the research is the development of the informational tools for the systematic assessment of the potential of the innovative development of a territory.

During the research the complex and systematic approach were used within which the methods of the comparative, retrospective, statistical and criteria analysis were used.

The suggested methodology of the assessment of the potential of the innovative development of a territory is based on the research of qualitative and quantitative indices using the method of the hierarchies' analysis. The components of the potential of the innovative development of a territory are the following ones: natural and territorial, industrial, scientific and technical, educational, investment, infrastructural, organizational and managerial, cultural and historical, informational potentials. For the automatic data processing of the assessment of the potential of the innovative development of a territory working books in the Microsoft Excel Software were created that allows implementing the author methodology relative to any territory. The efficiency of the expert survey is achieved by means of use of the cloud service Google Disk.

Keywords_-potential of the innovative development; territory; assessment; method of hierarchy analysis; cloud service.

\section{INTRODUCTION}

For the moment the pace and the character of the social and economic development of a territory mainly depend on the level of its potential of the innovative development. At the same time one of contemporary tendencies is the fact that very often the leadership in the competition between regions win not the territories that initially had some advantages connected with the availability of scarce or unique resources but the territories whose leaders could create favourable conditions for the development, efficient and rational use of available resources and for the attraction of exterior ones. In this respect the assessment of the level of the potential of the innovative development of a territory seems to be an important and crucial problem. The goal of the research is the creation of informational tools for a systematic assessment of the potential of the innovative development of a territory.

Realized with the help of the grant of the Russian fund of fundamental research, scientific project № 15-46-02521.

\section{ASSESSMENT OF THE POTENTIAL OF THE INNOVATIVE DEVELOPMENT OF A TERRITORY}

The existing approaches to the assessment of the level of the potential of the innovative development of a territory (resource, resource and procedural, resulting, combined, competence, social ones [1-4 and others]) do not allow to estimate fully all the factors that influence its level. That's why the attempt was made to offer the author's approach for the solution of the problem mentioned above. In particular, the system of factors influencing the development of territories was formed, their description was made. On the basis of the showed factors and indicators of the innovative development the author's methodology of the assessment of the innovative development of a territory was developed. The attempt to render the process automated was made. As a result it became possible to determine not only the level of the potential of the innovative development of a territory but also the degree of the genius of the territory. In the author's opinion every territory can pretend to be genius at a competent and efficient management of a unique set of 
available and attracted resources of the region. The genius of a territory is supposed to be firstly revealed, then formed and after that developed in the way that the territory becomes exceptional. There are examples (Japan, the United Arab Emirates and other countries) when the territory without having unique natural resources in the beginning achieved considerable results in the sphere of social and economic development. The territory cannot be found genius as it has unique peculiarities that are clear and attractive for residents, business community and they are used efficiently in the maximal way.

Thus, in order to characterize the territory as a genius one it needs to have a number of basic potentials or to have uncontestable advantages in one or several of them including:

- natural and territorial potential including an advantageous geographic situation (location of a territory relative to city agglomerations, federal borders, capital of the state and large strategically important megapolises and others); natural conditions (types and unique character of natural resources, volume of extraction and deposits of natural resources, total surface of the territory, forests, surface of lands and arable lands, surface of undeveloped territories, landscape of the territory, availability of the resources of the animal world, availability and quality of unique natural resources (medical mud, mineral waters and so on); climatic conditions (type of climate, temperature regime, precipitation, wind, humidity, mist); ecological conditions (quality of sources and the level of the air pollution, volume of sewage waters, polluted emissions into the atmosphere, quantity of refuse, class of danger of refuse, ways of stacking and recycling and so on);

- industrial potential including the condition of the industrial complex (index of the industrial production, condition of fixed assets, capital productivity, level of the innovative activity of enterprises, index of activity in the energy saving and so on); condition of the construction industry; condition of agriculture;

- R\&D (scientific and technical) potential (R\&D funding, quality of scientific and research organizations, quantity of the stuff in the sphere of research, quality and quantity of innovative projects and so on);

- educational potential (quantity and efficiency of higher educational institutions, percentage of lecturers of higher educational institutions with the highest qualification (doctors and candidates of sciences), volume of funding of the education, quality and availability of the educational services and so on);

- investment potential (volume of investments into capital assets, volume of foreign investments, level of investment capacity, level of investment adaptive capacity and so on);

- infrastructural potential including the condition of the transport infrastructure (length and quality of automobile roads and railroads, naval waterways, availability of transportation by automobile, railway, water transport and so on); condition of communal infrastructure (level of equipment of houses, density of communal nets of the suburban zone, volume of services in water supply, water removal, heat supply, volume of refuse removal and so on); condition of social infrastructure (quantity of hospitals, volume of financing in the sphere of healthcare, quantity of museums, art galleries, art halls, theatres, cinema theatres, clubs, libraries, volume of financing in the sphere of culture, quantity of sports institutions and so on); condition of the tourist infrastructure (quantity of hotels, hostels, sanatoriums, pensions), average quantity per year of tourists and so on.

- organizational and managerial potential (quantity and quality of the realized target programs of the development of the territory, percentage of expenses for the implementation of target programs in the city budget, quantity of developed and approved normative and legislative papers in the sphere of the development of the territory and so );

- labour potential including social and demographic conditions (quantity of population, level of natural birth and life expectancy of population); labour conditions (employment of the working population of the suburban zone, coefficient of permanency, percentage of the employed population with higher education); standard of life of population (level of monetary income of the population, level of the minimal cost of living, index of consumer prices, average pension, average surface of dwelling units and so on);

- cultural and historic potential (quantity and quality of historic sights, quantity and quality of unique cultural sites, quantity of cultural traditions, quantity of unique fairy tales and so on);

- informational potential (percentage of users having access to the Internet, level of the provision of the population with mobile telephones, personal computers, quality and quantity of TV programs, radio stations, published newspapers and journals, regional informational, educational and internet resources (sites) and so on).

The author methodology of the assessment of the potential of the innovative development of the territory is based on the method of the analysis of hierarchies [5] and includes such levels of the research like target, factors, criteria, indices of the assessment and the territory itself (figure 1).

The table processor Microsoft Excel was used for the informational provision of the calculation of the level of factors and the potential of the innovative potential of a territory. The created working books that were made to implement the author methodology for the assessment of the innovative potential of the development of a territory. Besides at the realization of the operational survey of experts the form using the cloud service Google Disk was created. The access to the questionnaire could be realized using the link that was sent to all the experts via e-mail. The results of the on-line survey were accumulated in the Excel form of the space Google Disk. The processing of these materials allowed getting the total picture of the condition of the potential of the innovative development of the studied territories. 


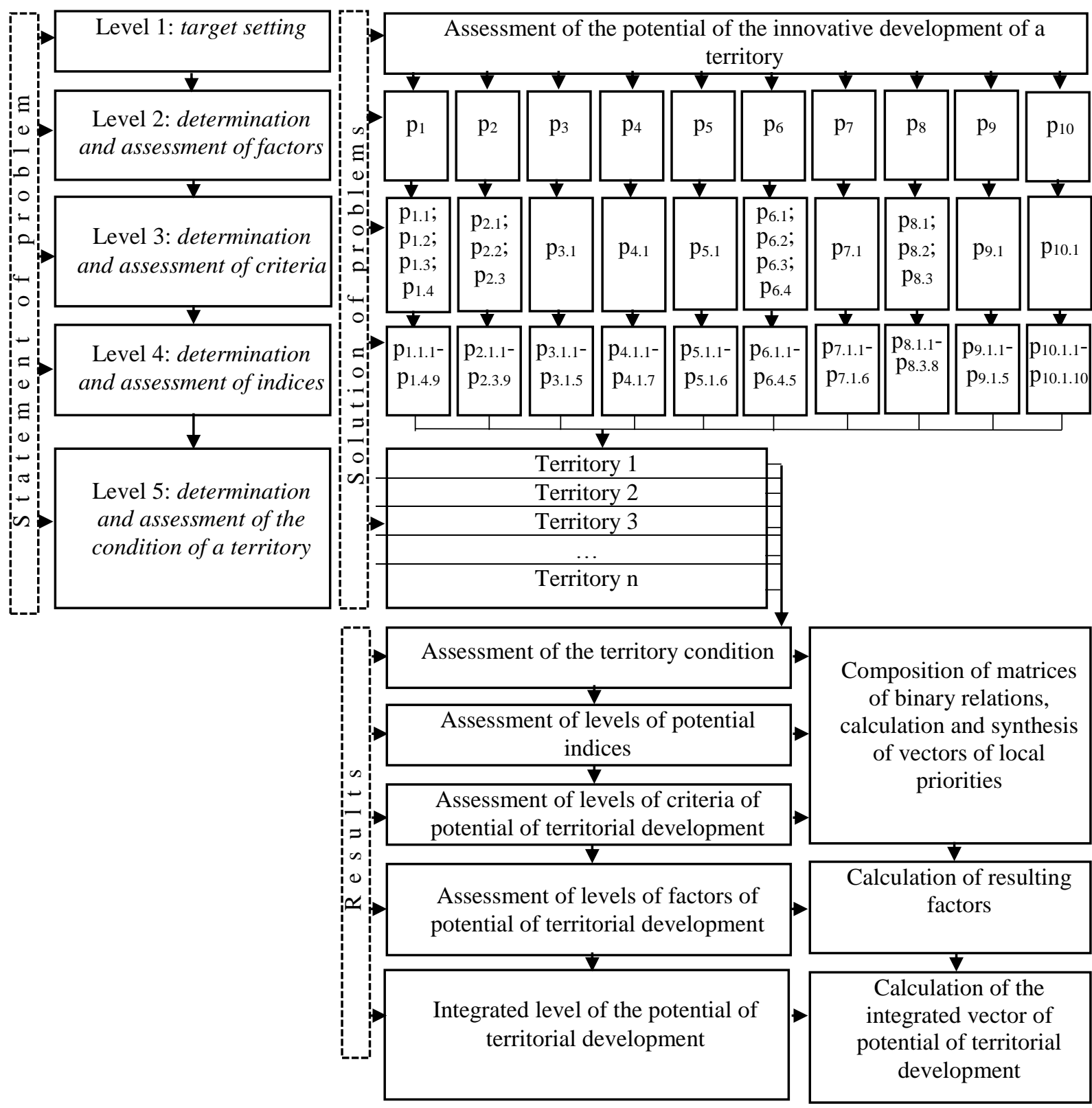

FIG. 1. PATTERN OF THE ASSESSMENT OF THE POTENTIAL OF THE INNOVATIVE DEVELOPMENT OF A TERRITORY

The approval of the elaborated methodology of the assessment of the potential of the innovative development of the territory and the informational tools was made using the information of large suburban zones of the Southern federal district of Russia in the Astrakhan, Volgograd, Rostov regions and Krasnodar kray.

In the process of the approval of the methodology of the potential assessment of the innovative development of suburban zones the statistical data was gathered and matrices of binary relation of values in 139 indices of the assessment of the factor potential of the innovative potential of the territory were made. After that the binary comparison of the studied suburban zones was made. The assessment of the level of factors of the potential of the innovative potential of the territorial development was realized.
Besides the procedure of the synthesis of local priorities vectors was realized. A number of local priorities from the matrix of binary comparisons was chosen and they express the influence of a relative number of the multitude of indices on the factor. The values of the vectors of local priorities of the matrix of binary comparisons of territories using the indices of the potential assessment of the innovative development were found. For the calculation of the integral level of the potential of the innovative development of the territory the procedure of the synthesis of the resulting vectors of priorities in accordance with the level of its factors was used. For the adjustment of the correctness of use of the method of hierarchies analysis and for the assessment of the developed model indices, 
coefficients and relations of coordination for every matrix of binary relations were calculated [6, c. 61].
The results of the assessment of the potential of the innovative development of large suburban zones of the Southern federal district of Russia are shown in the table 1.

TABLE 1

ASSESSMENT OF THE POTENTIAL OF THE INNOVATIVE DEVELOPMENT

OF LARGE SUBURBAN ZONES OF THE SOUTHERN FEDERAL DISTRICT OF RUSSIA

\begin{tabular}{|c|c|c|c|c|}
\hline \multirow{2}{*}{ Index } & \multicolumn{4}{|c|}{ Region } \\
\hline & Astrakhan region & Volgograd region & Krasnodar kray & Rostov region \\
\hline 1. Natural and territorial potential & 0,229 & 0,238 & 0,328 & 0,237 \\
\hline 2. Industrial potential & 0,142 & 0,164 & 0,307 & 0,285 \\
\hline $\begin{array}{l}\text { 3. R\&D potential (Scientific and technical } \\
\text { potential) }\end{array}$ & 0,093 & 0,132 & 0,260 & 0,433 \\
\hline 4. Educational potential & 0,141 & 0,163 & 0,196 & 0,413 \\
\hline 5. Investment potential & 0,131 & 0,115 & 0,262 & 0,343 \\
\hline 6. Infrastructural potential & 0,138 & 0,162 & 0,332 & 0,294 \\
\hline 7. Organizational and managerial potential & 0,135 & 0,110 & 0,347 & 0,401 \\
\hline 8. Labour potential & 0,195 & 0,153 & 0,312 & 0,273 \\
\hline 9. Cultural and historic potential & 0,154 & 0,250 & 0,370 & 0,229 \\
\hline 10. Informational potential & 0,172 & 0,163 & 0,247 & 0,370 \\
\hline $\begin{array}{l}\text { 11. Spark lines of the factors of the potential of } \\
\text { the innovative development of a territory }\end{array}$ & & & & \\
\hline $\begin{array}{l}\text { 12. Potential of the innovative development of a } \\
\text { territory }\end{array}$ & 0,153 & 0,165 & 0,296 & 0,328 \\
\hline 13. Rating assessment of the territory & IV & III & II & I \\
\hline
\end{tabular}

The realized research showed that the suburban zone of the Rostov region has the highest potential of the innovative development of the territory in the Southern federal district. This fact is explained by the leadership in such potential factors like scientific and technical, educational and informational potentials. A high level of the potential of the innovative development of a territory has the Krasnodar suburban zone. Its basic competitive advantages are natural, historic and cultural factors. A comparatively low potential of the innovative development of the territory is observed in Astrakhan and Volgograd suburban zones. In our opinion for an efficient development of these territorial zones the primary importance has a number of measures concerning the increase of the industrial, scientific and technical, infrastructural, organizational and managerial, informational potentials.

The evolution of cities encourages the development of their suburbs as a dense city construction, complexity and impossibility of the reorientation of use of some territories (large inefficient industries) impede an efficient and rational use of the territory as well as the social and economic development of the region. In modern conditions the intensification of the process of suburban development is explained by the following circumstances:

- availability of a large number of rarely built-up or free territories of suburban zones;

- comparatively low cost of property, low rent of industrial apartments (buildings), dwelling units;

- lower tax and tariff rates used in suburban zones;

- beneficial ecological situation in suburban zones;

- increase of the automobiles rate and the development of other transport communications;
- opportunity of a precise spatial division, creation of functional zones;

- necessity of modernization of the construction base of the soviet period;

- refuse of the highly dense multilevel buildings;

- possible location of mobile innovative highly precise industries and so on.

\section{CONCLUSION}

Thus the informational tools for the assessment of the potential of the innovative development of territories allows estimating in an integrated way the existing and potential opportunities of a region and to determine the direction of the successful development of territories. The basic components of the potential of the innovative development of a territory are the natural and territorial potential, industrial, scientific and technical, educational, investment, infrastructural, organizational and managerial, cultural and historic, informational potentials.

\section{REFERENCES}

1. Blyakhman L.S. Ekonomicheskaya effektivnost' deatelnosti regionalnogo nauchnogo kompleksa [Economic efficiency of the activity of the regional scientific complex], Leningrad: Nauka, 1986, $158 \mathrm{p}$.

2. Efimov V.P. Metodologicheskiye problemy ekonomii resursov [Methodological problems of resources saving], Moscow: Mysl', 1977, 286 p.

3. Maksimchiuk O.V., Klyushin V.V. Upravleniye strategicheskim ekonomicheskim potentsialom predpriatiy [Management of the strategic potential of enterprises], Volgograd, 2006, 175 p. 
4. Misko K.M. Resursniy potentsial regiona. Teoreticheskiye i metogologicheskiye aspekty issledovania [Resource potential of a region. Theoretical and methodological aspects of research], Moscow: Nauka, 1991, $94 \mathrm{p}$.

5. Saati T., Kerns K. Analiticheskoye planirovaniye [Analytic planning], Moscow: Radio i Svyaz, 1991, 224 p.
6. Sokolova S.A. Metodicheskiye podkhody k otsenke potentisala innovatsionnogo razvitia territoriy sovremennykh prigorodnykh zon [Methodological approach to the assessment of the potential of the innovative development of territories of contemporary suburban zones]// Gumanitarniye, sotsialno-ekonomicheskiye i obschestvennye nauki [Humanitarian, social, economic and public sciences], 2014, № 9, pp. 57-63. 